\title{
Analysis on the Characteristics of the Neoclassical Art
}

\author{
Liang Yan ${ }^{1,}$ a , Chongzhou Fei ${ }^{1, b}$, * \\ ${ }^{1}$ College of Architecture and Urban-Rural Planning, Sichuan Agricultural University, Chengdu \\ 611830, China. \\ a51027540@qq.com, b79434920@qq.com
}

\begin{abstract}
When people asked for the natural human rights, an unprecedented revolutionary movement happened in France in the late eighteenth century, and it had a profound impact on the history and culture of the whole world. Art has also been changed and developed in this historical moment, among which neoclassicism is one of the most representative artistic trends. The neoclassical movement took place before the political and social revolution of the French Revolution. Neoclassicism is the revival of ancient Greek art and ancient Rome art, and it pursues the solemnity, elegance, beauty and quietness of classical style. Its existence is against and criticizes Baroque art and Rococo art embodying the spirit of feudal aristocracy.
\end{abstract}

Keywords: Neoclassicism, enlightenment thought, aesthetics, painting, architecture.

\section{Introduction}

The aesthetics trend existed before the neoclassicism is court art of feudal aristocracy represented by Baroque art and Rococo art. Baroque art, produced in the late sixteenth century of Europe, contains many kinds of art, including painting, music, and architecture. It is characterized by intense emotional expression, being enthusiastic and unrestrained. It stops pursuing the balance, solemnity, and suggestiveness of the classical art which has existed since the Renaissance. The original meaning of Rococo art is "shell decoration" or "rock decoration". It is a highly skilled decorative art, mostly using $\mathrm{S}$ shape and spiral shape curve to show the characteristics of delicacy, magnificence, complex and beauty. This style has been popular all the time, it pursues visual pleasure, comfort and practicality, and has the tendency to exclude and belittle spiritual content [1].The greatest success of Baroque art and Rococo art happened in France in 17th century. In the period of Louis XIV, XV and XVI, Baroque art and Rococo art finally became a kind of hedonistic aesthetics of the feudal aristocracy, especially the architectural art. Take Versailles as example, the whole palace is decorated with pure gold, crystal chandelier and kitsch paintings of nude women (the style of Rococo art).During this period, ballet was developed and palace art was also created. The life and art of the entire Royal aristocracy is full of a sense of aesthetics which is eroded, rich, luxurious, dispirited and decadent. It is the reason that leads to the fall of the whole society. In this period, with the development and spread of enlightenment thought, the problem between the bourgeoisie and the feudal aristocracy was becoming obvious and the revolution was becoming inevitable, which also provided a historical opportunity for the emergence of neoclassicism. The purpose of neoclassicism is to criticize and oppose Baroque art and Rococo art represented by feudal aristocracy.

\section{The Characteristics of Neoclassicism}

\subsection{Nature Advocating}

There was an unnatural aesthetic pursuit of European aristocrats in the eighteenth century. They believed the true beauty is the beauty which is against natural senses. (What classical aesthetics pursues is natural beauty.) For example, it is popular that women liked to tighten the waist with their corsets, thus making their breasts plumper. In order to reduce the size of the waist to 17 inches, the women had to undergo a plastic operation to remove their two ribs at the bottom of the chest. The result of this plastic surgery is that all organs in the body are compressed into the chest. (The footbinding in China is also against nature.) Women used whale bones to lift up their clothes to show their oversized buttocks, while men wore wigs and put a fake nevus on their faces, and they also wore 
tight pants and high heels, speaking in a weird tune. In the landscape art, people also tend to use an unnatural geometric design. Plants and water system are geometrically pruned and designed.We cannot deny that the aesthetic consciousness of the nobility is beautiful. However, this kind of beauty is not natural and it is against the rule of natural beauty. At that time, the intellectuals began to criticize the aesthetic customs of the Royal aristocracy. Rousseau was one of the representatives. He believed that human beings should advocate nature, return to nature and follow the natural order. He thought it was beautiful that every leaf was swaying in the wind, rather than the "beauty" which was artificially disguised. Before the French Revolution, due to the influence of the scientific spirit and the enlightenment, a large number of European intellectuals came to the Greek and the surrounding Mediterranean coast to carry out scientific archaeology. They excavated and collected the art of architecture and sculpture of ancient Greek, restored the Athens Acropolis, and discovered the vicissitudes, simplicity and cleanness of the simple aesthetics hidden in the Greek pillars. The simple aesthetics replaced the curve design of the Baroque art. Neoclassicism took off the flourishing ornamentation of Baroque architecture, removed the ornaments of flowers and flowers, and let people rediscover the beauty of the mechanics of the columns, and make the columns "stand upright".At that time British artists began to change the garden style of the French Palace of Versailles and let the plants grow freely. People began to have a new understanding of the beauty of Baroque, which is in violation of the beauty of nature. British garden designers began to learn the design concept of oriental gardens. Designers built Greek buildings in the gardens and began to yearn for ancient Greece and Rome.The tenet of neoclassicism is to make architecture simple. The supporters of neoclassicism believe that "simplicity" is beauty, and they want to make the building "pure" again. In 18th century, the British landscape architect believed that nature was a park. A group of landscape architects in England, such as Kent and Brown, have demolished the high enclosed walls of classical geometric gardens and included natural scenery into the gardens. British garden, which is nature advocating, has become an important style in the history of world gardens. In the view of the supporters of neoclassicism, a courtyard or garden should reflect the beauty of nature, and should focus on some fascinating scenery[2]. One of the characteristics of neoclassicism is advocating nature.

\subsection{Classical Advocating}

Denis Diderot, the author of the Encyclopedia, began to publicly criticize the court Rococo painters represented by Boucher, and criticize the court painters represented by Boucher. He thought that they would only use beautiful colors to describe the beauty of mythology and the love of men and women. He also attacked the woman's white skin, dazzling lips and graceful posture which are created by Francois Boucher. He accused them of drawing only "women's breasts and hips" to satisfy the nobility's taste of vulgarity and desire. These works also reflect the aesthetic tendency of the court during the period of Louis XV. Diderot thought that a painter couldn't be a qualified painter without moral and sentiments, and a painter should have noble character in addition to skills. While the intellectuals represented by Diderot criticized the aesthetics of the aristocracy, criticized the court painters and criticized the Rococo art, they needed a standard to make comparison with them, so ancient Greece and ancient Rome classical art were the best choice. A large number of ancient Greek sculptures, such as Venus, were dug out, and Diderot thought that the human body of the ancient Greek was the ideal and natural beauty, instead of the sensual sense of flesh which was showed by the court painters represented by Francois Boucher. He hoped that the art could return to classicism. Classicism refers to the ideal beauty of harmony in ancient Greece and ancient Rome, and the aesthetic feeling of solemn elegance, natural magnificence and advocating rationalism. The "neoclassicism" is made up with "new" before "classicism", which aims to be different from classicism. Neo classicism is mainly to publicize the Republican spirit of the great revolution and the aesthetic embodiment and the fashion of the times, which is dedicated to its motherland. On the other hand, it also reflects its spirit of advocating classical style and developing the art of the ancient Greek Rome. 


\subsection{Revolutionary Classicism}

In the whole history of European Art, there are several artistic ideological trends which wanted to "revive" the ancient times. The first trend was the Renaissance, and the second one was in France in 17th century. A common feature of the two revivals is the concern for people.In ancient Greek and Rome, people praised for man, while Christianity worshiped gods in Middle Ages; during the period of Renaissance, people began to concern about the humanity, while people praised for monarchical power when the Baroque art is popular. The beginning of neoclassicism also illustrates that people have returned to the idea of self-awakening of "human".As the founder of modern law, Rousseau's social contract theory is the cornerstone of modern democratic system. He thought that the law should follow the natural law and put forward that "natural human rights" should replace the "divine right of king".Rousseau believed that the ancient Greeks were free. As a city state, Greece carried out the democratic system and the people participated in the election.Greece is the birthplace of democracy. (In fact, Greek democracy is not what we imagine, nor is it so democratic, but intellectuals at that time must carry out the revolution under the banner of "Greek democracy".)In the form of Greek architecture, we can deeply feel the power of democratic thought. The strong Greek columns support the building, symbolizing that people would support the country, and it is also a metaphor for democratic thought. Influenced by the French Revolution and neoclassicism, it is not difficult to explain why many of the buildings after the independence of the United States have adopted the neoclassical style, instead of the baroque style, and the aim is to highlight the Democratic thoughts. Rousseau and other intellectuals were very enthusiastic about Greece. They beautified Greece, brought the Greek spirit of democracy, Greek architecture, and sculpture back to France, and made neoclassicism known as "revolutionary classicism" with the help of the ancient Greek democratic ideology.

\subsection{Using the Past to Criticize the Present}

Voltaire, another ancient philosopher, influenced the masses through drama and inspired the masses. Because drama has the greatest influence on the masses, he put revolutionary ideas in the drama to expose the crimes of the king and criticize the accomplices of the rulers. For example, Voltaire used the story of King Caesar and Brutus in ancient Rome to write the drama "Verbatim", which was to publicize the revolution through the theme of ancient Rome. The theme of this drama is that Brutus's sons got killed because Brewster defended the Republic against King Caesar. Voltaire publicized to the public through drama that there must be sacrifice in the revolution. "The attendants bring the corpses of the sons of Brutus" which was painted by Jacques Louis David, the founder of neoclassicism, is the stage background of Voltaire's drama "Verbatim" and is now collected in Le Louvre Museum. David reflected the times by using the heroic deeds of ancient Greece and Rome, which means that the reason that Neoclassicism broke out on the eve of the revolution is to "use the past to criticize the present".

\subsection{The Imprint of the Times}

There is a famous painting named The Death of Marat in France. This painting is also a representative work of Jacques Louis David, the founder of neoclassicism. Marat, one of the leaders of the French Revolution, was the chief editor of the "Friends of the People". He attacked the French feudal dynasty and publicized the republican ideology, which made him hated by the royalists. In order to avoid persecution, he spent hours hiding in a cellar, and it made he suffer from eczema. He had to soak in the bathtub for several hours every day and deal with work and documents. One day, the royalist assassin, Charlotte Codie, stabbed him to death. David was Marat's best friend, and he saw the death of Marat with his own eye. David painted every word on the letters in Marat's hand to reveal the atrocities of the feudal ruling class. The whole picture is still and dignified, omitting all the details and striving for simplicity, without complicated colors and complicated perspectives and props. Although this painting shows a terrible assassination, the painter does not exaggerate blood and terror, but rather depicts the sublime and tranquility of Mara's death. It can be seen that the painter always 
follows the principles of classical art in his creation and try to keep more reason [3]. It also reflects that the neoclassical art creation needs to keep up with the imprint of the times.

\section{Conclusion}

From the above, the writers, philosophers, artists and architects played a vital role in the French Revolution and the enlightenment to the people, and promoted the development of the revolution. In the history of art, it is the first time that the painter (David), participated in politics. The greatest symbol of neoclassicism is that art should take part in social life. The artists are not hermits who are intoxicated in their own world. Instead, they have responsibility to participate in the social movement and inspire the masses. (What Mr. Xu Beijing was studying in the west is neoclassicism, so it was not difficult to explain why $\mathrm{Mr}$. $\mathrm{Xu}$ was a mark of the art world during the Period of the Republic of China and the period of the People's Republic of China.) Therefore, "neoclassicism" not only is an ideological trend of art and culture, but also reflects the return of the rational spirit, the awakening of humanism and the advocating of natural aesthetics. Its thoughts involve many fields of art and deep influence, making neoclassicism become the inevitable result of historical development.

\section{References}

[1]. Chen Leonia. Outline of the History of Foreign Art. Southwestern Normal University Press. July 2005, p. 117.

[2]. Yang Ping. The Genealogy of Environmental Aesthetics. Nanjing Publishing House. September 2007, P. 47.

[3]. Chen Leonia. Outline of the History of Foreign Art. South-western Normal University Press. July 2005, P. 124. 